\title{
Reflective Assessment of Learning Outcomes [RALO] in Basic Medical Sciences Subjects - [TAU MODEL]
}

\author{
Article by Arulsamy Anand \\ Vice Chancellor, Texila American University, Guyana, South America \\ E-mail:vc@tau.edu.gy
}

\begin{abstract}
The assessment of learning outcomes at the program level has been a topic of international interest as a method for quality assessment and ongoing program quality enhancement. According to UNESCO report, increasing global integration and exchange of both students and instructors has been an important international objective in higher education in recent years. This trend requires institutions to identify standards of quality, resulting in an increased emphasis on both learning outcomes and evidence from course assessments to demonstrate that students have mastered the expected learning.

Medical educators are increasingly laying emphasis in the assessment and learning outcome, and over a period of time standardized assessment methods like, OSPE and OSCE came into existence and they are widely used in many institution and also by the international examining bodies worldwide.

However, there aren't many assessment methods devised, wherein the medical students themselves can assess their level of understanding in basic medical sciences. Continuous methods of understanding the level of knowledge gained by a student will give him/her insight into his learning outcomes and as well as to the teachers.

This concept paper provides an overview of experience gained in developing a selfassessment methods of learning outcome of the medical students.

In 2014 Texila American University created the concept of Reflective Assessment of Learning Outcome, initially this method of assessment was experimented on the distance and blended learning programs, having found it to be very effective in terms of understanding the learning outcomes, this model was implemented for the Doctor of Medicine [MD] students in the year 2016.
\end{abstract}

Keywords: RALO - Reflective Assessment of Learning Outcome.

\section{Introduction}

\section{History of reflective learning}

The origins of thinking and writing about reflection started in the last century when John Dewey (1933) first described the concept and how it could help an individual to develop thinking and learning skills.

Dewey defined the concept of reflection as "the active, persistent and careful consideration of any belief or supposed form of knowledge in the light of the grounds that support it and the further consideration to which it tends" (Dewey, 1933).

A wider recognition of the importance of reflection for learning emerged in the mid-1980s in the work of David Kolb (1984) who suggested that learning can happen as result of reflection on experience- experiential learning. He suggested that reflection enables the experiential learner to move through steps from concrete experience to sense-making through reflection. Learners can explore abstract conceptualization- the application of theory- which informs further action and new experiences.

At the same time in the early 1980s the concept of reflection was developed further by Donald Schön (1982), a social scientist. He developed the idea of reflecting on experience to gain professional knowledge and develop professional skills in his seminal book The Reflective Practitioner: How Professionals think in action. 


\section{Reflective learning}

\section{Reflective learning enables one}

- To accept responsibility for his own personal growth

- To see a clear link between the effort one has put into his/her development activity and the benefits he/she get out of it

- To help see more value in each learning experience, by knowing why he/she is doing it and what's in it for him/her

- Learn how to 'learn' and add new skills over time.

\section{Reflecting on learning}

Reflecting on learning enables an individual to link his professional development to practical outcomes and widens the definition of what counts as useful activity. Quite simply, one need to keep asking 'what did I get out of this?'

As a reflective learner, an individual will think about how he will use new knowledge and skills in his future activities - so learning is always linked to action, and theory to practice. It's also useful to reflect on how he learn best.

\section{How often one should reflect on his learning?}

Reflection should become a routine part of college life that is more or less instinctive. People who routinely plan, record and reflect on their learning tend to see more opportunities for personal development.

Reflection also involves drawing forth cognitive and emotional information from several sources: visual, auditory, kinesthetic, and tactile. To reflect, one must act upon and process the information, synthesizing and evaluating the data. In the end, reflecting also means applying what one has learned to contexts beyond the original situations in which he learned something.

\section{What is Reflective Assessment of Learning Outcome [RALO]}

This is a self-assessment done by the students on the learning outcomes. Student learning outcomes articulate what a student should know or can do after completing a course or program. Reflective assessment of learning outcome helps the students to check their mastery level obtained based on the learning outcome determined in the syllabus. Students determines his/her level of understanding of the learning outcomes

\section{Why student self-assessment?}

"Self-assessment by pupils, far from being a luxury, is in fact an essential component of formative assessment. When anyone is trying to learn, feedback about the effort has three elements: recognition of the desired goal, evidence about present position, and some understanding of a way to close the gap between the two.

\section{Benefits for students}

- Development of metacognitive skills - students become more skilled at adjusting what they are doing to improve the quality of their work (Cooper, 2006).

- Increased responsibility for students' own learning as a result of more opportunities for self-reflection (Cyboran, 2006).

- Positive effects for low achievers -reducing achievement gaps (Black \& Wiliam, 1998; Chappuis, \& Stiggins, 2002).

- Development and refinement of students' capacity for critical thinking (Cooper, 2006)

\section{RALO feedback and growth continuum}

RALO provides a concrete feedback on the learning outcomes and as well the comparison between the objective and subjective assessment. RALO can also prove to be a feedback system for the teachers to know how effectively they had imparted their classes. This 
feedback will act as benchmark for the curriculum committee to make necessary modifications in determining the outcomes

Ralo feedback and growth continuum

\begin{tabular}{|c|c|c|c|c|}
\hline & Students & Faculty & & Institution \\
\hline $\begin{array}{l}\text { Learning } \\
\text { Outcomes }\end{array}$ & $\begin{array}{l}\text { What is expected to } \\
\text { be learned by the } \\
\text { students by the end of } \\
\text { the course }\end{array}$ & $\begin{array}{lr}\text { Focus on } & \text { CORE } \\
\text { Competencies. } & \text { Learning } \\
\text { outcomes are determined } \\
\text { based on knowledge, Skills } \\
\text { and Attitude } \\
\text { competencies }\end{array}$ & & $\begin{array}{l}\text { Update the learning outcomes } \\
\text { for an appropriate mastery }\end{array}$ \\
\hline $\begin{array}{l}\text { Teaching } \\
\text { Learning } \\
\text { Activities } \\
\text { [TLA] }\end{array}$ & $\begin{array}{l}\text { Effectively participate } \\
\text { in the TLA }\end{array}$ & $\begin{array}{l}\text { Application of identified } \\
\text { strategies for achieving the } \\
\text { expected learning outcome }\end{array}$ & & $\begin{array}{l}\text { Modify the teaching learning } \\
\text { methods for a better outcome }\end{array}$ \\
\hline $\begin{array}{l}\text { Continuous } \\
\text { and } \\
\text { Summative } \\
\text { Assessment }\end{array}$ & $\begin{array}{l}\text { Participates in } \\
\text { Objective Assessment }\end{array}$ & $\begin{array}{l}\text { Assessment developed to } \\
\text { assess the learning outcome } \\
\text { objectively }\end{array}$ & & $\begin{array}{l}\text { Refining the Assessment } \\
\text { pattern }\end{array}$ \\
\hline $\begin{array}{l}\text { RALO } \\
\text { Assessment }\end{array}$ & $\begin{array}{l}\text { Self-Assessment by } \\
\text { the Students on the } \\
\text { Learning } \\
\text { Outcomes[Subjective] }\end{array}$ & $\begin{array}{l}\text { Comparison between } \\
\text { Objective and Subjective } \\
\text { Assessment }\end{array}$ & - & $\begin{array}{l}\text { Feedback to curriculum } \\
\text { committee }\end{array}$ \\
\hline
\end{tabular}

Figure 1. RALO feedback and growth continuum chart, shows the connection to the learning outcome, its assessment and feedback from the assessment leading to the modification of the teaching learning activities and eventually refinement of the learning outcomes

\section{Reflective assessment of learning outcomes [RALO] in basic medical sciences subjects- [TAU MODEL]}

\section{Objectives of RALO}

Students need to learn how to assess their own progress by asking themselves some key questions about where they are in their learning: Where am I now? Where am I trying to go? What do I need to get there? How will I know I have accomplished what I set out to do?

\section{To help students determine where they are now, teachers can...}

- Ensure that students understand the criteria for quality work, so that they are able to assess themselves as fairly and accurately as possible

- Help students gradually assume more responsibility for their own learning, as they practice using self-assessment tools such as RALO

- Provide students with opportunities to discuss their self-assessments in light of peer and teacher assessments

- Ensure that all stakeholders provide specific anecdotal feedback rather than scores or grades to identify explicit next steps for student learning

To help students determine where they intend to go, teachers can ...

- Develop with students clearly articulated learning targets and provide concrete exemplars of student work; students need to understand what they're "aiming for".

- Model goal-setting for students. 


\section{To help students determine what they need to do to get there ...}

- Collaboratively identify strengths and gaps in student learning through the analysis of a variety of data.

- Help students to develop realistic action plans that are practical and directly linked to the learning goals that have been selected.

- Monitor students' progress as they implement action plans.

To help students determine whether they have accomplished what they had set out to do...

- have students revisit long-term learning goals periodically to reflect on their relevance and to make any necessary adjustments

- talk with each student about his/her learning goal(s)

- have students write a specific reflection about their learning outcome and what they did to achieve them - students may need guidance to identify their strengths and areas for improvement

\section{Methods}

- All basic medical science teachers were informed about the RALO process and they were advised to check the appropriateness of the learning outcome of their respective subjects.

- The learning outcome were made known to the students and it was published in the learning management system.

- Teachers deliver the courses through various teaching learning methodologies

- At the end of the course the students were advised to do a self-assessment and rate themselves their level of achieving competencies over the subject matter. This was done through the learning management system

\section{Results}

The results of the RALO of all the four levels of classes are given below

\section{Discussion}

\section{Mapping the learning outcome with peers}

Through RALO assessment students can compare their understanding of the learning outcomes with their classmates. This provides more insight into their learning and understanding. The following gives the overall RALO scores of a class, an individual student can rate himself against the given learning outcome and compare it with the overall class score

The following is the overall RALO Score of MD-1[2016] class in Medical Embryology. An individual student can compare his level of learning with the overall learning outcome of his class 


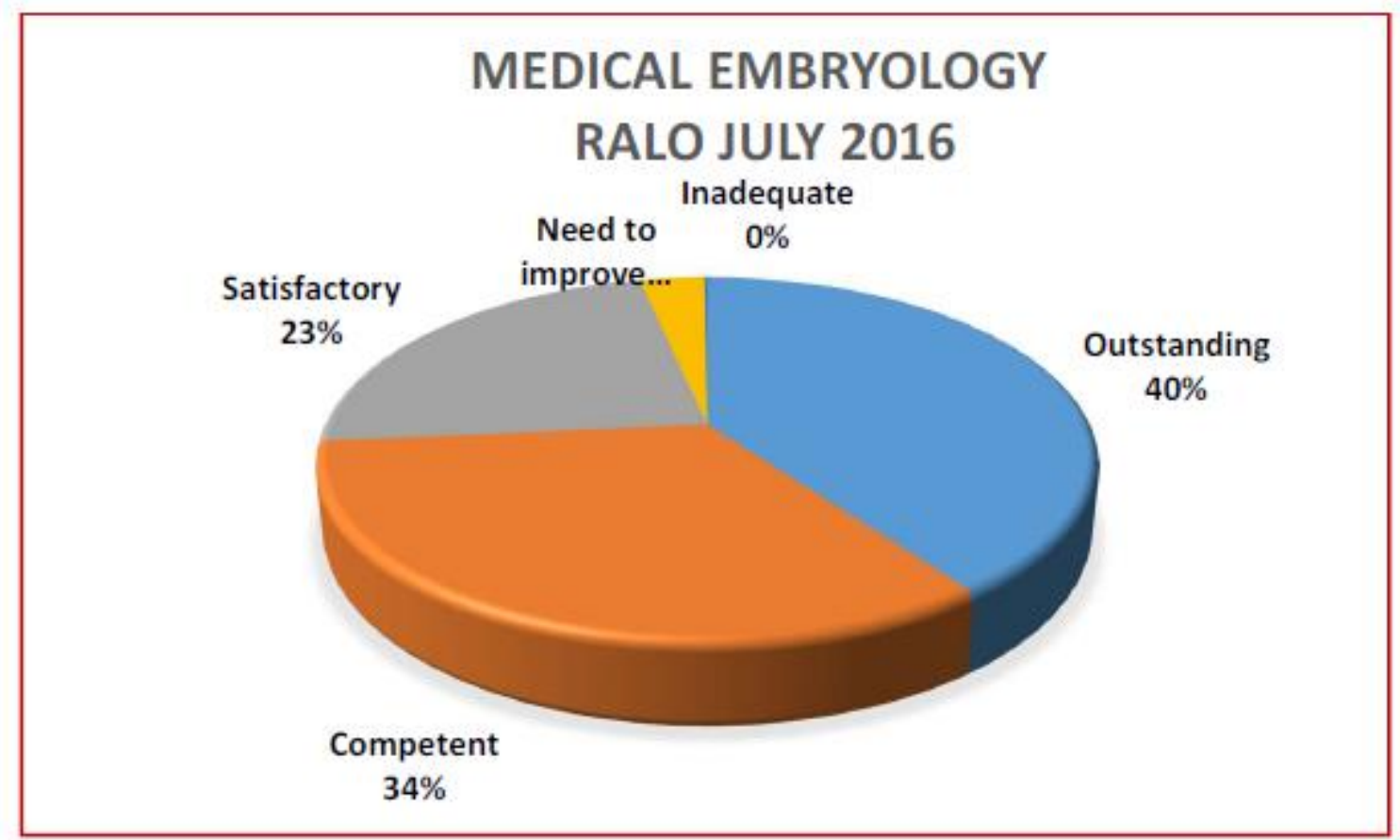

Figure 2. Class rating on the learning outcomes of the subject Medical Embryology

\section{RALO assessment}

Students to rate the following learning outcome based on their level of competency as 5: Outstanding 4: Competent 3: Satisfactory 2: Need to improve 1: Inadequate Upon completion of the course, students will be able to:

\begin{tabular}{|c|c|c|}
\hline S.No & Responses & Score \\
\hline 1 & $\begin{array}{l}\text { Understand and describe human gamete biology, embryology and } \\
\text { developmental biology from a cellular and genetic perspective }\end{array}$ & \\
\hline 2 & $\begin{array}{l}\text { Describe the key events in early and systematic embryological } \\
\text { development }\end{array}$ & \\
\hline 3 & Apply developmental theory of anatomical development & \\
\hline 4 & $\begin{array}{l}\text { Apply developmental theory to abnormalities of development and } \\
\text { current medical research techniques }\end{array}$ & \\
\hline 5 & $\begin{array}{l}\text { Students are able to broadly understand the abnormalities in the } \\
\text { development and current applications in medical research }\end{array}$ & \\
\hline 6 & $\begin{array}{l}\text { Identify and define key structural and molecular elements involved in } \\
\text { each stage of human development, the precursors of each structure, } \\
\text { and the functional significance of each structure }\end{array}$ & \\
\hline 7 & $\begin{array}{l}\text { Construct a temporal sequence of key events in each developmental } \\
\text { period }\end{array}$ & \\
\hline 8 & $\begin{array}{l}\text { Explain and identify the normal embryological anatomy and identify } \\
\text { anomalies in the development of various tissues through a comparison } \\
\text { of normal and abnormal development }\end{array}$ & \\
\hline 9 & $\begin{array}{l}\text { Understand, using a comparative approach, the key differences in } \\
\text { embryological development across animals }\end{array}$ & \\
\hline 10 & $\begin{array}{l}\text { Accurately and effectively communicate scientific ideas through } \\
\text { written assignments and reports within the lab and a case study } \\
\text { presentation }\end{array}$ & \\
\hline
\end{tabular}


DOI: 10.21522/TIJBMS.2016.02.02.Art006

ISSN: $2519-500 \mathrm{X}$

An individual can score himself against the learning outcome for the subject Medical embryology and total his score and percentage in the table given below and compare it with his peers

\begin{tabular}{|l|l|l|l|l|}
\hline S.No & $\begin{array}{l}\text { Score and Level of } \\
\text { Understanding }\end{array}$ & Total Score & Percentage & Class \% \\
\hline 1 & 5: Outstanding & & & $40 \%$ \\
\hline 2 & 4: Competent & & & $34 \%$ \\
\hline 3 & 3: Satisfactory & & & $23 \%$ \\
\hline 4 & 2: Need to improve & & & $3 \%$ \\
\hline 5 & 1: Inadequate & & & $0 \%$ \\
\hline
\end{tabular}

\section{Summary}

After the assessment is complete, those faculty and/or other parties most involved in the RALO, analyze the results and determine how to use them to improve students' success in achieving Learning Outcomes. For example, they might decide to change or augment instruction in a particular way, change curriculum, or improve future RALO assessments in a specific way.

\section{References}

[1]. Altbch, P.G., Reisberg, L, \& Rumbley, L.E. (2009). Trends in global higher education. Tracking an academic evolution. United Nation Educational, Scientific, and Cultural Organization. Retrieved from

[2]. Bruce, L. B. (2001). Student self-assessment: Encouraging active engagement in learning. Dissertation Abstracts International, Vol. 62-04A, 1309.

[3]. Driscoll, A. and Wood, S. (2007). Developing outcomes-based assessment for learner-centered education: A faculty introduction. Sterling, VA: Stylus.

[4]. Jonson, J. (2006). A guidebook for programmatic assessment of student learning outcomes: University of Nebraska, Lincoln. University of Nebraska, Lincoln: office of Undergraduate Studies.

[5]. Rolheiser, C., \& Ross, J.A. (2000). Student self-evaluation - What do we know? Orbit, 30(4), 33-36.

[6]. Shoemaker, J. (2008). Guidelines for writing student learning outcomes. University of California, Irvine: Assessment \& Research Studies, Division of Undergraduate Education. Irvine, CA. 